\title{
MANUSIA DALAM PERSFEKTIF PSIKOLOGI DAN ISLAM
}

\author{
Rosmita \\ Jurusan Pengembangan Masyarakat Islam \\ Fakultas Dakwah dan Komunikasi Universitas Islam Negeri Sultan Syarif Kasim Riau \\ Email: rosmita@uin-suska.ac.id
}

\begin{abstract}
Abstrak
Manusia sebagai makhluk hidup yang merupakan makhluk yang lebih sempurna apabila dibandingkan dengan makhluk makhluk hidup yang lain. Manusia tidak semata mata tunduk pada kodratnya dan secara pasif menerima keadaannya, tetapi ia slalu sadar dan aktif menjadikan dirinya sesuatu. Proses perkembangan manusia sebagian ditentukan oleh kehendaknya sendiri, berbeda dengan makhluk makhluk lainnya yang sepenuhnya tergantung pada alam. Kebutuhan untuk terus menerus menjadi inilah manusia yang khas manuasiawi, dan karenanya pulalah manusia bisa berkarya, biasa mengatur dunia untuk kepentingannya, sehingga timbullah kebudayaan dalam segala bentuknya itu, yang tidak terdapat pada makhluk lainnya.
\end{abstract}

\section{Pendahuluan}

Banyak sarjana yang mencoba untuk mendefinisikan tentang manusia. E.Cassiner menyatakan,:"manusia adalah makhluk simbolis",dan plato merumuskan," Manusia harus dipelajari bukan dalam kehidupannya, tetapi dalam kehidupan sosial dan politiknya, sedangkan menurut faham filsafat eksistensialisme " manusia adalah eksistensi”. Manusia tidak hanya ada atau berada di dunia ini, tetapi ia secara aktif "mengada". 11

Manusia juga merupakan makhluk dinamis dalam pengertian bahwa manusia dapat mengalami perubahan perubahan. Tingkahlaku manusia dapat berubah dari waktu ke waktu karena manusia mempunyai kelebihan dan kemampuan kemampuan yang membedakan manusia dengan ciptaan Allah yang lainnya. Yaitu kemampuan berfikir dan berkemauan (streven). Di samping itu manusia mempunyai kata hati, dan hanya pada manusialah adanya kemampuan untuk menghubungkan diri dengan Tuhan. ${ }^{12}$

Pada manusia terdapat macam macam kebutuhan yang muncul pada setiap saat. Kebutuhan yang pertama yang dipenuhi yang pertama adalah kebutuhan akan makanan dan oksigen, yaitu kebutuahn yang bila tidak dipenuhi akan menyebabkan manusia itu tidak dapat mempertahankan hidupnya. Kebutuhan seperti ini disebut kebutuhan dasar

\footnotetext{
${ }^{11}$ Dr.Sarlito Wirawan Sarwono, Pengantar Umum Psikologi, Jakarta, Bulan Bintang, 1976, hlm. 21

${ }^{12}$ Dr. Bimo Walgito, Pengantar Psikologi Umum, Yogyakarta, Andi, 2002, hlm.34
} 
atau kebutuhan primer atau kebutuhan fisiologis. Akan tetapi manusia tidak mungkin dapat hidup secara wajar, sejahtera, sehat dan berbahagia apabila kebutuhan primer saja yang dipenuhi. Manusia membutuhkan sesuatu yang lain, yaitu yang dapat memberinya perasaan sejahtera dan bahagia, seperti kebutuhan akan ujian, kasihsayang, keleluasan bertindak, perasaan aman dan bebas, dan sebagainya. Kebutuhan yang terakhir ini bersifat psikis dan para ahli menamakannya kebutuhan sekunder atau kebutuhan psikologis. ${ }^{13}$

\section{A. Manusia dan Perkembangannya}

Telah dijelaskan di atas, manusia itu merupakan makhluk hidup yang lebih sempurna apabila dibandingkan dengan makhluk hidup yang lain. Akibat dari unsur kehidupan yang ada pada manusia, manusia berkembang dan mengalami perubahan perubahan baik perubahan dalam segi fisiologis maupun dalam perubahan psikologis. Adapun teori perkembangan itu adalah ;

\section{Teori nativisme}

Teori ini mengatakan bahwa perkembangan manusia ditentukan oleh faktor faktor nativus, yaitu faktor faktor keturunan yang merupakan faktor faktor yang dibawa oleh individu pada waktu dilahirkan. Individu dilahirkan telah membawa sifat sifat tertentu, dan sifat sifat inilah yang akan menentukan keadaan individu yang bersangkutan ,sedangkan factor lain. Yaitu lingkungan ,termasuk didalamnya pendidikan dapat dikatakan tidak berpengaruh terhadap perkembangan induvidu itu. ${ }^{14}$

Teori ini menimbulkan pandangan bahwa seakan akan manusia telah ditentukan oleh sifat sifat sebelumnya. Yang tidak dapat diubah, sehingga individu akan sangat tergantung kepada sifat sifat yang diturunkan oleh orang tuanya. Apabila orang tuanya baik seseorang akan menjadi baik, sebaliknya apabila orang tuanya jahat seseorang akan menjadi jahat.

\section{Teori empirisme}

Teori ini menyatakan bahwa perkembangan seorang induvidu akan ditentukan oleh empirinya atau pengalaman pengalamannya yang diperoleh selama perkembangan induvidu itu.dalam pengertian pengalaman termasuk juga pendidikan yang diterima induvidu. Menurut teori ini induvidu yang dilahirkan itu sebagai kertas atau meja yang putih bersih yang belum ada tulisan tulisannya. Teori ini juga dikenal dengan teori tabularasa.

\footnotetext{
${ }^{13}$ Singgih Dirgagunarso, Pengantar Psikologi, Jakarta, Mutiara Sumber Widya, 1982, hlm.94-95

${ }^{14}$ Bigot,dkk, Leerboek der Psychologie, J.B. Wolters-Groningen, Jakarta, 1950, hlm.35
} 


\section{Teori konvergensi}

Teori ini merupakan teori gabungan (konvergensi) dari kedua teori tersebut diatas,yaitu suatu teori yang dikemukakan oleh wilyam sterm baik oembawaan maupun pengalaman atau lingkungan mempunyai induvidu akan ditentukan factor yang dibawa sejak lahir (factor endogen) maupun factor lingkungan (termasuk pengalaman pendidikan) yang merupakan factor eksogen. ${ }^{15}$

Teori inilah dapat yang diterima oleh para ahli pada umumnya. Sehingga teori yang dikemukakan oleh wilyam sterm merupakan salah satu hukum perkembangan iduvidu disamping adanya hukum hukum perkembangan yang lain. Di indonesia teori konvergensi inilah yang kiranya dapat diterima, seperti yang dikemukakan oleh ki Hajar Dewantara:

“Tentang hubungan antara dasar dan keadaan ini menurut ilmu pendidikan ditetapkan adanya "konvergensi" yang berarti bahwa kedua-duanya saling mempengaruhi, hingga garis dasar keadaan itu selalu tarik menarik dan akhirnya menjadi satu. Mengenai perlu tidaknya tuntunan di dalam tumbhunya manusia,samalah keadaannya dengan soal perlu atau tidaknya pemeliharaan dalam tumbuhnya tanam-tanaman. ${ }^{16}$

Perkembangan dapat diartikan sebagai The Progesive and Continuous change in the organism from to death (sesuatau perubahan yang progesif dan kontinu dalam diri induvidi dari mulai lahir sampai mati). Perkembangan daoat juga diartikan sebagai perubahan yang dialami oleh induvidu atau organisme menuju tingkat kedewasaannya atau kematangannya (maturation) yang berlangsung secara sistematis (saling kebergantungan atau saling mempengaruhi antara bagian bagian organisme merupakan suatu kesatuan yang utuh), progresif (bersifat maju, meningkat dan mendalam baik secara kunatitatif maupun kualitatif) dan berkesinambungan (secara beraturan, beruntun bukan secara kebetulan) menyangkut fisik maupun psikis. ${ }^{17}$

Pertumbuhan manusia sejak dalam kandungan sudah ditentukan polanya, dan tiap sel tubuh berkembang sesuai dengan garis perkembangannya masing masing semuanya mengarah kepada suatu tujuan untuk menjadi makhluk manusia dengan organ organnya yang tersusun secara harmonis. Demikianlah, meskipun pada hari hari pertama kandungan sel sel janin nampaknya serupa saja semuanya (homogen), tetapi pada tingkat

\footnotetext{
${ }^{15}$ Bimo Walgito, Op.cit, hlm.36

${ }^{16}$ Ki Hajar Dewantara, Karya K.H. dewantara, Majelis Luhur Taman Siswa, Yogyakarta, hlm. 22

${ }^{17}$ H. Syamsu Yusuf, M.Pd, Psikologi Perkembangan Anak dan Remaja, Bandung Remaja Rosdakarya, 2002, hlm. 50
} 
perkembangan selanjutnya sebagian dari sel sel itu akan berkembang menjadi jantung. Lainnya jadi otak, jadi tangan, kaki dan sebagainya, sehingga akhirnya terjadilah seorang manusia yang sempurna. ${ }^{18}$

Menurut Ibnu qoyyim fase perkembangan dapat diartikan sebagai penahapan atau pembabakan rentang perjalanan kehidupan individe yang diwarnai ciri ciri khusus atau pola pola tingkah laku laku tertentu. Masalah pembabakan atau periodesasi perkembangan ini, para ahli berbeda pendapat. Pendapat pendapat tu secara garis besarnya dapat digolongkan menjadi tiga, yaitu berdasarkan analisis biologis, didaktis, dan psikologis.

Ciri ciri khusus dan pola pola tingkah laku yang dimiliki oleh setiap induvidu dalam setiap tahapan perkembangan merupakan hasil dari proses fase perkembangan sebelumnnya, ada keterkaitan antara satu fase denga fase yang lain. Persiapan dan pembinaan orang tua ketika induvidu yang bersangkutan masih kecil sangat mempengaruhi proses proses perkembangan selanjutnya. Induvidu hanya membawa potensi-potensi ketika ia lahir,orang tua yang harus membentuk atau mengembangkan semua potensi yang dimiliki anak. Sampaipun ketika ketika induvidu berada pada fase lansia, merupakan hasil dari persiapan dan pembinaan orang tuanya ketika ia masih dalam fase-fase sebelum fase dewasa. ${ }^{19}$

\section{PANDANGA ISLAM TENTANG MANUSIA}

1. Istilah Manusia dalam al-Quran

Al-Qur-an merupakan bacaan sempurna lagi mulia,tiada bacaan yang melebihi Al qur-an yang dibaca rtusan juta orang baik yang memahami betul maknanya maupun yang tidak dapat menulis dengan aksaranya.

Tiada bacaan seperti al Qur-an yang memuat berbagai konsep tentang kehidupan yang menjelaskan berbagai permasalahan yang dituangkan dari sumber yang tidak pernah kering. Semuanya menyandang kebenaran. Al qur'an layaknya sebuah permata yang memancarkan cahaya, laksana purnama yang menerangi kegelapan. Darinya kita dapat mengetahui, dan mengenal tentang berbagai macam konsep yang berhubungan dengan kehidupan, baik yang fisik maupun yang non fisik. Suatu Dari sekian permasalahan yang dibahas oleh Alqur'an yang acap kali menjadi bahan kajian yang sering dinilai secara

\footnotetext{
${ }^{18}$ Sarlito Wirawan Sarwono, Op.Cit, hlm.23

${ }^{19}$ Netti Hartati, dkk, Islam dan psikologi, Jakarta, PT.Raja Grafindo Persada, 2004, hlm. 17-18
} 
spekulatif, yang didasarkan pada pandangan yang sangat subjektif dan tidak disandar pada pegangan yang benar benar dipercaya yakni tentang konsep mausia. Konsep manusia adalah konsep sentral bagi setiap diiplin ilmu social adalah konsep sentral bagi setiap disiplin ilmu social kemanusiaan yang menjadikan manusi sebagai objek formal dan materialnya. Agar konsep manusia yang kita bangun bukan semata mata merupakan konsep spektulatif, maka kita mesti bertanya pada zat yang mencipta dan mengerti manusia yaitu Allah SWT, melalui Alqur'an. ${ }^{20}$ Lewat Alqur'an Allah memberikan rahasia- rahasia tentang manusia. Karenanya, kalau kita ingin mengetahui manusia lebih nyata, benar dan sungguh maka Al qur'an memberikan gambaran tentang manusia sebagai berikut:

a. Menggunakan kata yang teridiri dari huruf alif, nun dan sin semacam insane, ins, nas atau unas.

b. Menggunakan kata bsyar

c. Menggunakan kata bani adam, dan Zuriyat Adam. ${ }^{21}$

Manusia dinamai basyar karena memiliki kulit yang jelas, dan berbeda dengan kulit binatang yang lain. Proses kejadian manusia sebagai basyar, melalui tahap -tahap sehingga mencapai tahap kedewasaan. Sebagimana dijelaskan dalam Al qur'an : “dan diantara tanda -tanda kekuasaanya menciptakan kamu dari tanah kemudian ketika kamu menjadi basyar kamu bertebaran. $^{22}$

Kata insane terambil dari kata uns yang berarti jinak,harminis, dan gampak. Kata insane digunakan Al qur'an untuk menunjukkan kepada manusia dengan segala totalitasnya, jiwa dan raga. Manusia yang berbeda antara seseorang dengan yang lain. Akibat perbedaan fisik, mental dan kecerdasan. ${ }^{23}$

\section{Produksi dan Reproduksi Manusia}

Menurut Al qur'an, manusia menempati posisi istiimewa di alam jagat raya ini. Manusia adalah wakil tuhan dimuka bumi. Sebagaimana dinyatakan dalam al qur'an :" Dan ingatlah tatkala tuhanmu berkata kepada malaikat sesungguhnya aku akan

\footnotetext{
${ }^{20}$ Abdul Rahman Saleh, dkk, Psikologi Dalam Persfektif Islam, Jakarta, Prenada Media, 2004, hlm. 48-49

${ }^{21}$ Ibid, hlm.50

${ }^{22}$ Q.S. Al-Ruum, Ayat 20

${ }^{23}$ M.Shihab, Wawasan Al-Qur'an, Bandung, Mizan, 1996, hlm.12
} 
menjadikan seorang khalifah di muka bumi". ${ }^{24}$ Dan manusia yang menyandang gelar sebagai khalifah Allah diatas muka bumi yang diciptakan tuhan melebihi dari makhluk makhluk yang lainnya. Al qur'an menjelaskan bahwa manusia diciptakan dari tanah,kemudian setelah sempurna kejadiannya, tuhan menghembuskan kepadanya ruh ciptaannya. Dengan "Tanah" manusia dipengaruhi oleh kekuatan alam seperti makhluk makhluk yang lain,sehingga butuh makan, minum,hubungan seks dan sebagainya. Dan "ruh" dia diantar ke arah tujuan non materi yang tak berbobot dan tak bersubstansi dan tak dapat diukur di laboratorium atau bahkan dikenal oleh alam material.

Manusia yang benar benar khalifah allah adalah manusia yang mempunyai kondisi baik,berperangai halus. Karena khalifah di muka bumi ini hrauslah menjadi seorang pemimpin rasulullah dan para sahabatnya.

Al-Qur'an tidak memandang manusia sebagai makhluk yang tercipta secara kebetulan atau tercipta dari kumpulan atom, tapi ia diciptakan setelah sebelumnya direncanakan untuk mengemban satu tugas "Sesungguhnya Aku hendak menjadikan khalifah di muka bumi." Ia dibekali Tuhan dengan potensi dan kekuatan positif untuk mengubah corak kehidupan ke arah lebih baik, serta ditundukkan dan dimudahkan kepadanya alam raya untuk dikelola dan dimanfaatkan, ditetapkan arah yang harus dituju, dan dianugerahkan kepadanya petumjuk untuk menjadi pelita dalam perjalanan ini. ${ }^{25}$

Al-Qur'an menguraikan produksi dan reproduksi manusia ketika berbicara tentang penciptaan manusia pertama, Al-Qur'an menunjukkan kepada sang pencipta dengan menggunakan penggantian nama tunggal. Untuk hal ini diterangkan dalam Al-Qur'an :"Sesungguhnya Aku akan menciptakan manusia dari tanah". ${ }^{26}$ Penciptaan manusia secara umum, melalui proses keterlibatan Tuhan bersama selain-Nya yaitu ibu bapak. Keterlibatan ibu dan bapak mempunyai pengaruh dan bentuk fisik dan psikis manusia.

Al-Qur'an tidak menguraikan secara rinci proses penciptaan Adam sebagai manusia pertama. Al-Qur'an hanya menyampaikan :

a. Awal manusia adalah dari tanah

b. Bahan tersebut disempurnakan

\footnotetext{
24 Abdurrahman Saleh Abdullah, Teori-teori Pendidikan Berdasarkan Al-Qur'an, Jakarta, Rineka Cipta, 1994, hlm.46

${ }^{25}$ Q.S. 2:38

${ }^{26}$ Q.S, Shaad:71
} 
c. Setelah proses penyempurnaan selesai, ditiupkan padanya Ruh Ilahi. ${ }^{27}$ Mengenai apa dan bagaimana proses penyempurnaan itu tidak disinggung oleh Al-Qur'an. AlQur'an hanya menguraikan proses pertama, pertengahan dan akhir.

3. Potensi Manusia Dalam Al-Qur'an

Al-Qur'an banyak membicarakan manusia, diantaranya yang dibahas adalah mengenai sifat-sifat dan potensinya. Al-Qur'an banyak sekali mengungkap, memuja dan memuliakan manusia. Seperti pernyataan tentang diciptakannya dalam bentuk yang sebaik baiknya.

Potensi manusia sebagaimana dijelaskan oleh Al-Qur'an melalui kisah Adam dan Hawa, bahwa sebelum kejadian adam, Allah telah merencanakan agar manusia memikul tanggungjawab kekhalifahan di bumi. Untuk maksud tersebut Allah memberikan akal dan ruhani inilah Allah berikan beberapa potensi kepada manusia, diantaranya :

a. Potensi untuk mengetahui nama-nama dan fungsi benda benda alam

b. Pengalaman hidup di surga, baik yang berhubungan dengan kecukupan dan kenikmatannya, maupun rayuan Iblis adan akibat buruknya.

c. Petunjuk-petunjuk agama. $^{28}$

Potensi-potensi inilah yang diberikan Allah kepada manusia, yang menjadikannya berbeda terhadap makhluk- makhluk lainnya.

\section{Ciri ciri Manusia Dalam Pandangan Al-Qur'an}

Adalah benar bahwa manusia bukanlah suatu entitas yang homogen. Tetapi suatu kenyataan yang heterogen yang tak jarang carut marut yang tidak teratur. Penulis menyadari bahwa membicarakan manusia berarti membicarakan sesuatu yang sulit, karena banyaknya persoalan yang terkandung dalam diri manusia itu, sulit untuk didekati secara menyeluruh. Namun, penulis berpendapat sesulit apapun suatu pekerjaan atau masalah sedapat mungkin dapat dilakukan atau diselesaikan. Salah satu umpamanya merumuskan pandangan tentang manusia. Cara dan Al hadist. Menurut Haan Djumhana Bastman sebagaimana dikutip oleh Jamaludin Ancok, mengatakan wawasan islam mengenai manusia banyak sekali sumbernya khususnya dalam Al qur'an yang diwirayatkan melalui kisah-kisa Adam AS. Dari sana dapatlah diketahui bahwasanya manusia itu meiliki potensi potensi yang meliputi:

1. Manusia itu mempunyai derajat yang sangat tinggi sebagai khalifah Allah

\footnotetext{
${ }^{27}$ Q.S, Al-Hijr:71-72

${ }^{28}$ Abdul Rahman Saleh, Psikologi, Op.Cit, hlm, 53-54
} 
2. Manusia tidak mengandung dosa asal turunan

3. Manusia merupakan kesatuan dari empat dimensi, fisik-biologis, mental psikis, sosio-kultural, dan spriritual.

4. Dimensi spritual (rohani, roh-ku) memunhkinkan manusia mengadakan hubungan dan mengenal tuhan melalui cara cara yang di ajarkan nya.

5. Manusia memiliki kebebasan berkehendak (freedom of will) yang memungkinkan manusia untuk secara sadar mengarahkan dirinya ke arah yang keluruhan atau kearah kesesatan .

6. Manusia memiliki akal sebagai kemampuan khusus dan dengan akal itu mengembangkan ilmu sertan peradaban.

7. Manusia tidak dibenarkan hidup tanpa bimbingan dan petunjuknya. ${ }^{29}$

Selain potensi-potensi tersebut diatas, maka kita dapat mengenal manusia daan membedakannya dari makhluk makhluk yang lain melalui ciri-cirinnya, yaitu:

1. Manusia mempunyai raga dan bentuk yang sebaik-baiknya dengan rupa dan bentuk yang sebaik-baik nya ini diharapkan manusia menjadi beersyukur kepada Allah. (Q.S An- Nahl :78)

2. Manusia itu sebaik dari segi fitrah. Da tidak mewarisi dosa asal usulnya. Ciri utama fitrah manusia adalah menerima Allah sebagia tuhan.

3. Ruh, Al qur'an secara tegas menyatakan bahwa kehidupan manusia tergantung pada wujud ruh dan badan .

4. Kebebasan, kemauan atau kebebasan berkehendak, yaitu kebebasan umtuk memilih tingkah laku sendiri, kebaikan atau keburukan.

5. Akal, akal dalam pengertian islam, bukan otak melainkan daya berpikir yang terdapat dalam jiwa manusia. Akal dalam islam mempunyai ikatan pada tiga unsur yakni pikiran,persaan ,dan kemauan.

6. Nafs, nafs atau nafsu serigkali dikaitkan dengan gejolak aatau dorongan yang terdapat dalam diri manusia apabila dorongan itu brrkuasa dn manusia tidak mengendalikannya. Maka manusia akan tersesat. Kesesatan tersebut terjadi karena manuia yang dikuasai nafsuny itu tidak menggunakan hati dan indra (mata dqan tilinga yang dimilikinya) 


\section{Kesimpulan}

Dari uraian dapat disimpulkan bahwa manusia sebgai makhluk hidup yang kebih semourna. Yang kebih derajatnya,dan yang lebih mulia sisi tuhan dibanding makhluk lainnya. Semua itu dinicarakan oleh para ahli psikologi dan begitu juga terdapat dalam Al qur'an

Manusia dijadikan khalifah oleh Allah agar dapat mengurus dan memimpin dunia ini dengan segala kelebihan dan keisimewaan dunia ini dengan segaala kelebihan dan berupa: 1.) potensi untuk mengetahui nama-nama dan fungsi benda benda alam. 2.) pengalaman hidup disurga,baik yang berhubungan dengan kecukupan dan kenikmatanyya, maupun rayuan iblis dan akibat buruknya 3.)petunjuk-petunjuk agama.

\section{DAFTAR KEPUSTAKAAN}

Sarlito Wirawan Sarwono,Dr, Pengantar Umum Psikologi, Jakarta, Bulan Bintang, 1976, Bimo Walgito, Dr, Pengantar Psikologi Umum, Yogyakarta, Andi, 2002 Singgih Dirgagunarso, Pengantar Psikologi, Jakarta, Mutiara Sumber Widya, 1982 Bigot,dkk, Leerboek der Psychologie, J.B. Wolters-Groningen, Jakarta, 1950

Ki Hajar Dewantara, Karya K.H. dewantara, Majelis Luhur Taman Siswa, Yogyakarta Syamsu Yusuf, M.Pd, Psikologi Perkembangan Anak dan Remaja, Bandung Remaja Rosdakarya, 2002

Netti Hartati, dkk, Islam dan psikologi, Jakarta, PT.Raja Grafindo Persada, 2004 Abdul Rahman Saleh, dkk, Psikologi Dalam Persfektif Islam, Jakarta, Prenada Media, 2004

Q.S. Al-Ruum, Ayat 20

M.Shihab, Wawasan Al-Qur'an, Bandung, Mizan, 1996

Abdurrahman Saleh Abdullah, Teori-teori Pendidikan Berdasarkan Al-Qur'an, Jakarta, Rineka Cipta

Q.S. 2:38

Q.S, Shaad:71

Q.S, Al-Hijr:71-72 